\title{
Word Formation Processes of the Terms Related to Covid-19 and Environmental Issues in The Jakarta Post
}

\author{
Widya Ratna Dewati ${ }^{1 *}$ and Catur Kepirianto ${ }^{1}$ \\ ${ }^{1}$ English Department, Faculty of Humanities, Diponegoro University, Semarang - Indonesia
}

\begin{abstract}
The outbreak of the COVID-19 pandemic which spreadly affected many things including the environment caused many mass media like newspapers to publish the news about it. The purposes of the research are to present the word-formation processes of terms related to COVID-19 and environmental issues found in five articles in The Jakarta Post newspaper. It is descriptive-qualitative research. The word-formation processes were reviewed to describe how the terms related to Covid-19 and the forms of environmental issues. The data collected by the note-taking technique are analyzed morphologically. Results of the research showed that there are some types of word-formation processes such as borrowing, compounding, blending, clipping, acronym, derivation, and multiple processes. These are the sample data of borrowing: pandemic; compounding: lockdown; blending: oxide that comes from oxygene + acide; clipping: oxide that comes from ox- -ygene (back clipping) + ac- -ide (fore clipping); acronym: COVID-19 (Corona Virus Disease 2019); derivation: agricultural that comes from agriculture- $+-a l$; and multiple processes: post-COVID. The most common word formation process found are borrowing and compounding.
\end{abstract}

\section{Introduction}

The outbreak of the Covid-19 pandemic, which lasted more than one year, has affected many aspects, including the environment. Moreover, in 2021, the issues regarding Covid-19 and environmental issues are the hot topic that makes many people discuss it. There is also much news about Covid-19 and environmental issues in every mass media, such as newspapers. The Jakarta Post is an Indonesian daily newspaper that uses English as the language in its contents. The Jakarta Post posted some articles related to Covid-19 and environmental issues. In presenting the news, there are new terms regarding Covid-19 and environmental issues that are important for us to know its word-formation process.

The new vocabularies and terms can be related and analyzed by the word-formation process, which includes morphological aspects as one of the linguistics branches. The wordformation process is the different tools that use existing words to create new ones. Each wordformation process produces a distinct sort of word [1].

\footnotetext{
*Corresponding author: widyadewati@gmail.com
} 
According to Yule, there are ten types of word-formation processes [2]. They are coinage, borrowing, compounding, blending, clipping, backformation, conversion, acronym, derivation, and multiple processes [2]. The researchers use those word-formation processes to analyze the types of word-formation related to Covid-19 and environmental issues in the newspaper articles. Each of the types has its definition, which is different from others.

Coinage is the process of inventing a new term from a trading name or a product on the market that has become a general term, such as nylon, vaseline, and the zipper. The practice of borrowing a word from another language is known as borrowing. For example, the word jewel is from French. Compounding is the process of merging two forms to generate a new word, such as textbook and sunburn. Blending is the process of joining two distinct forms by selecting only the initial or the ending of one word and combining it to create a new word, such as motel (motor/hotel). Clipping is the reduction process of a multi-syllable word into a shorter form, such as a fan (fanatic). Backformation is the procedure of trimming a word of one kind (typically a noun) to another type (typically a verb). For instance, the word babysitter, a noun, came first before the word babysit, a verb. Conversion is the process of changing the function of a word without reducing it, such as the word water in a sentence. Would you water my plants? The acronym takes the first letter of a group of words and then combines them to create a new form, such as NYPD (New York Police Department) and CP (Contact Person). Many acronyms also have become standard terms, such as radar (radio detecting and ranging). The derivation is the process in which a word's meaning and category are separated from its base by adding affixes, such as playful or enjoyable. Last, the multiple processes. It is the process in which a word has more than one process at work, such as the word deli, which has two word-formations involved. They are borrowing delicatessen (from German) and clipping (back clipping).

There have been few studies about the word-formation process. Rahayu [3] analyzed the word-formation process of the terms used by online clothes shops in Blackberry Messenger. Fitria [4] analyzed the word-formation process in terms of the COVID-19 pandemic. Annisa Faradisa [5] analyzed word-formation processes found in Instagram.

The prior studies have distinctions from this research which centers on the wordformation process in the newspaper articles. The previous studies center on the wordformation process of the terms randomly in social media. Meanwhile, this research centers on the terms of Covid-19 and environmental issues collected from articles in the Jakarta Post newspaper.

Based on this fact, the study of word-formation of the terms related to Covid-19 and environmental issues may substantially impact English Department students, especially linguistic students. This study is necessary to investigate as the outbreak of Covid-19 has become a severe issue and affected many aspects, including the environmental aspect. This research presents the word-formation processes of terms related to Covid-19 and environment issues found in four articles in The Jakarta Post newspaper.

\section{Method}

This study is designed as qualitative research to describe processes or behavior to answer 'why' questions or to explain and comprehend the issue. This approach highlights extraordinary observation and centers more on the material of these phenomena' consequences. The power of the words and sentences used strongly influences the analysis in qualitative research.

The data collection procedure in this research is by using documentation. This research documents four articles related to Covid-19 and environmental issues in The Jakarta Post newspaper. The title of those four articles are COVID-19 opportunity to enhance our 
environmental commitments [6], Greenhouse gas levels at new high; despite COVID-19 measures [7], COVID-19 is clarifying the climate challenge [8], COVID-19 and environmental challenges: Two sides of a coin [9], and Air pollution fell, plastic use soared during Europe lockdowns [10].

The data were analyzed by using some steps. First, the researchers selected the articles related to Covid-19 and environmental issues in The Jakarta Post newspapers. Second, the researchers read the articles and found out the terms related to Covid-19 and environmental issues. After getting the data, the researchers analyzed the word-formation process in the data based on Yule's theory [2]. In Yule's theory, there are ten types of word-formation processes. They are coinage, borrowing, compounding, blending, clipping, backformation, conversion, acronym, derivation, and multiple processes [2]. They are divided based on how they are formed, such as combining, reducing, summarizing, or adopting from other languages. Next, the researchers classified the data based on its word-formation process.

\section{Result}

Table 1. Classified data of Terms related to Covid-19 and Environmental issues.

\begin{tabular}{|c|c|c|c|}
\hline No & $\begin{array}{c}\text { Types of word } \\
\text { formation }\end{array}$ & Terms related to Covid-19 and Environmental issues & Total \\
\hline 1 & Coinage & - & - \\
\hline 2 & Borrowing & $\begin{array}{l}\text { 1. pandemic, from Greek "pandemos" } \\
\text { 2. atmosphere, from Greek atmos (vapor, steam) + sphaira } \\
\text { (sphere). } \\
\text { 3. biosphere = from Greek bios + sphaira } \\
\text { 4. lithosphere = from German litho (stone) + from Greek } \\
\text { sphaira. } \\
\text { 5. cryosphere = from Greek kryos (cold) + sphaira (ball) } \\
\text { 6. oceans = from Old French "occean" } \\
\text { 7. epidemics = from French "epidemique" } \\
\text { 8. vaccine = from Latin "vacca" } \\
\text { 9. pollution = from Latin "pollutio" } \\
\text { 10. virus = from Latin "virus" } \\
\text { 11. plantation = from Latin "plantation" } \\
\text { 12. transmission= from Latin "transmissio" } \\
\text { 13. oxide = from France "oxygene" + "acide" } \\
\text { 14. agriculture = "agriculture" from Late Latin "agricultura" } \\
\text { 15. bio = from Greek "bios" } \\
\text { 16. contagious = from late Latin "contagio" } \\
\text { 17. infections = borrowing from old French "infeccion" } \\
\text { 18. emission = from old French "émission" }\end{array}$ & 18 \\
\hline 3 & Compounding & $\begin{array}{l}\text { 1. } \text { lockdown }=\text { lock }+ \text { down } \\
\text { 2. } \text { greenhouse }=\text { green }+ \text { house } \\
\text { 3. } \text { post-pandemic }=\text { post }+ \text { pandemic } \\
\text { 4. farmland }=\text { farm }+ \text { land } \\
\text { 5. } \text { peatlands }=\text { peat }+ \text { land } \\
\text { 6. public-health }=\text { public }+ \text { health } \\
\text { 7. low-carbon }=\text { low }+ \text { carbon } \\
\text { 8. coronavirus = corona }+ \text { virus } \\
\text { 9. ecosystems }=\text { eco }+ \text { system } \\
\text { 10. biodiversity }=\text { bio }+ \text { diversity } \\
\text { 11. atmosphere }=\text { atmos }+ \text { sphere } \\
\text { 12. biosphere }=\text { bios }+ \text { sphere } \\
\text { 13. lithosphere }=\text { litho }+ \text { sphere } \\
\text { 14. } \text { cryosphere }=\text { cryo }+ \text { sphere }\end{array}$ & 16 \\
\hline
\end{tabular}




\begin{tabular}{|c|c|c|c|}
\hline & & $\begin{array}{l}\text { 15. } \text { outbreak }=\text { out }+ \text { break } \\
\text { 16. } \text { short-term }=\text { short }+ \text { term }\end{array}$ & \\
\hline 4 & Blending & 1. oxide $=$ oxygene + acide & 1 \\
\hline 5 & Clipping & $\begin{array}{l}\text { 1. oxide }=\text { oxygene (back clipping) }+ \text { acide (fore clipping) } \\
\text { 2. eco }=\text { ecology (back clipping) }\end{array}$ & 2 \\
\hline 6 & Backformation & - & - \\
\hline 7 & Conversion & - & - \\
\hline 8 & Acronym & $\begin{array}{l}\text { 1. } \text { COVID-19= Coronavirus Disease } 2019 \\
\text { 2. } \mathrm{GHG}=\text { Green House Gases } \\
\text { 3. } \mathrm{FAO}=\text { Food and Agriculture Organization } \\
\text { 4. } \mathrm{CO} 2=\text { Carbon Dioxide } \\
\text { 5. SARS-CoV-2 = Severe Acute Respiratory Syndrome } \\
\text { Corona Virus } \\
\text { 6. } \mathrm{EEA}=\text { European Environment Agency } \\
\text { 7. } \mathrm{NO} 2=\text { Nitrogen Dioxide }\end{array}$ & 7 \\
\hline 9 & Derivation & $\begin{array}{l}\text { 1. environmental }=\text { environ }+ \text { ment }+ \text { al } \\
\text { 2. environment }=\text { environ }+ \text { ment } \\
\text { 3. } \text { sanitation }=\text { sanitary }+ \text { ion } \\
\text { 4. agricultural = agriculture }+ \text { al } \\
\text { 5. } \text { deforestation = de }+ \text { forest }+ \text { ation }\end{array}$ & 5 \\
\hline 10 & Multiple Process & 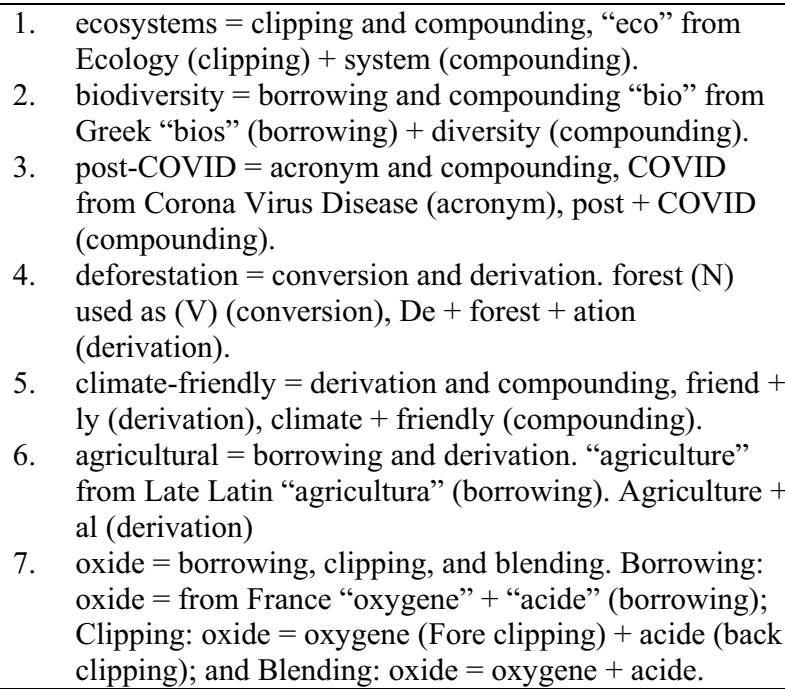 & 7 \\
\hline
\end{tabular}

\section{Discussion}

The word-formation process is the process of forming words. Each word-formation process produces a different sort of word. It is produced by the affixational process, which includes adding prefixes and suffixes to produce words with different meanings. Furthermore, it is the process of changing the format of a term from its origin by combining, reducing, summarizing, or adopting from other languages.

Coinage, borrowing, compounding, blending, clipping, acronym, derivation, conversion, backformation, and multiple-process are examples of word-formation processes. Borrowing is the process of switching a word from one language to another to be used in another language. Borrowing is the most common findings in this research. For example, the words pandemic that is borrowed from Greek, the word virus that is borrowed from Latin, the word epidemics that is borrowed from French, the word vaccine that is borrowed from Latin, and the word pollution that is borrowed from Latin. In this study, most of these words 
are borrowed from Latin and Greek. Many of these borrowed terms have undergone changes in writing, while others have not or are maintained entirely as they were initially.

In compounding, two words are merged to create a new word (common noun and adjective). For example, the words greenhouse, public-health, outbreak, and post-pandemic. 1) The term greenhouse is a word that consists of more than one morpheme. The first is green, and the second is house. 2) The term public-health contains two free morphemes public and health. 3) The term outbreak consists of two morphemes out and break. 4) The term post-pandemic consists of two morphemes, post, and pandemic.

Blending is a word-formation process that involves merging two or more words into a single form. In blending, not all the parts of the words are represented. The parts used are the parts of syllables and letters that can make them attractive, easy to listen to, and easy to pronounce abbreviations. For example, the word oxide comes from oxygen and acid. The parts are $o x$ and ide.

Clipping is the process of trimming the word without changing its meaning. In this study, there are two clippings found. They are oxide which comes from Oxygene (back clipping) + acid (fore clipping), and eco, which comes from the word ecology (back clipping).

In an acronym, there is abbreviating words by taking the first letter of a group of words and then combining them to create a new form. The acronym words aim to condense the meaning and solidify it so that it is easier to remember, especially for the general public. There are five findings of acronyms; COVID-19, GHG, FAO, CO2, and SARS-Cov-2. In this study, acronyms are used to describe terms about Covid-19, such as COVID-19 (Corona Virus Disease 2019) and SARS-CoV-2 (Severe Acute Respiratory Syndrome Corona Virus); to describe chemical terms such as CO2 (Carbon Dioxide) and GHG (Green House Gases), and to compact the meaning of organization such as FAO (Food and Agriculture Organization).

The derivation is the process of changing the meaning or the class of a word by adding affixes. There are at least three parts of the derivation process: root, prefix, and suffixes. In this study, there are five data found as derivation. One data changes from the verb to an adjective, such as environmental it comes from the environment- $+-m e n t+-a l$. One data changes from the verb to noun, such as the environment that comes from the environment- + -ment. One data changes from adjective to a noun, such as sanitation that comes from sanitary- + -ion. Then, one data changes from noun to an adjective such as agricultural that comes from agriculture- +- al. Aside from that, specific data do not modify the word class, but some affixes modify the root's meaning, such as the word deforestation that comes from de- + -forest- + -ion. It only changes the meaning, but it does not change the word class

The multiple processes consist of some word-formation processes in it. In this study, there are seven data found as multiple processes. For example, the word ecosystems contain clipping and compounding, the morpheme eco is clipped from ecology (clipping), and there is a combination of eco + system (compounding). In the word biodiversity, there is the process of borrowing and compounding the morpheme bio is borrowed from Greek bios (borrowing), and there is the combination of bio + diversity (compounding). The word postCOVID contains two processes. They are acronyms and compounding. The word COVID is abbreviated from Corona Virus Disease (acronym), and there is the combination of the word post + COVID (compounding).

In the word deforestation, there is the process of conversion and derivation. The word forest is noun used as a verb (conversion), and there is the combination of $d e-+$-forest+ -action (derivation).

\section{Conclusion}


The outbreak of Covid-19 affected many aspects, such as the environment. This led to the emergence of much news about it in various mass media, including newspapers. There are many new terms regarding Covid-19 and environmental issues that we must know how it is formed in the news. In this study, the word-formation processes were reviewed to describe how the terms related to Covid-19 and the forms of environmental issues. The wordformation processes can explain how words are formed so that they can be used and contain meaning. Word-formation also investigates the source of a word based on its history from a long time ago until it can be used in the present.

The word-formation processes form a word through the affixational process, which includes adding prefixes and suffixes to produce words with different meanings.

Furthermore, it is the process of changing the format of a term from its origin by merging, reducing, summarizing, or adopting from other languages.

The researchers found seven types of word-formation processes in this research. They are borrowing, compounding, blending, clipping, acronym, derivation, and multiple processes.

\section{References}

1. H. Jackson, E. Z. Amvela, Words, meaning and vocabulary: an introduction to modern English lexicology, (Cassell London, 2000)

2. G. Yule, The Study of Language, Fourth edi., (Cambridge University Press Cambridge, 2010)

3. P. R. Nim, Word Formation Processes of the Terms Used by Clothes Online Shops in Blackberry Messenger Thesis By Puji Rahayu Study Program of English Department of Languages and Literature Faculty of Cultural Studies, University of Brawijaya, (2014)

4. T. N. Fitria, Word formation process of terms in COVID-19 pandemic, Leks. J. Bahasa, Sastra dan Pengajarannya, 15(1), 18 (2021)

5. A. Faradisa, Z. A. Aziz, B.Yasin, An Analysis of Word Formation Processes Found in Instagram, READ., 2, 52-64 (2019)

6. P. Amri, K. Roesad, Y. R. Damuri, (2020), COVID-19 opportunity to enhance our environmental commitments, Retrieved from https://www.thejakartapost.com/academia/2020/05/05/covid-19-opportunity-toenhance-our-environmental-commitments.html

7. N. Larson, (2020), Greenhouse gas levels at new high, despite COVID-19 measures, Retrieved from https://www.thejakartapost.com/life/2020/11/27/greenhouse-gas-levelsat-new-high-despite-covid-19-measures.html

8. O. Macharis, N. Farajalla, (2020), COVID-19 is clarifying the climate challenge, Retrieved from https://www.thejakartapost.com/academia/2020/05/15/covid-19-isclarifying-the-climate-challenge.html

9. R. H. Efendi, (2020), COVID-19 and environmental challenges: Two sides of a coin, Retrieved from https:/www.thejakartapost.com/academia/2020/10/06/covid-19-andenvironmental-challenges-two-sides-of-a-coin.html

10. APF, (2020), Air pollution fell, plastic use soared during Europe lockdowns, Retrieved from https://www.thejakartapost.com/life/2020/11/06/air-pollution-fell-plastic-usesoared-during-europe-lockdowns.html

11. N. Triwahyuni, Imranuddin, Zahrida, an Analysis of Word Formation Encountered in Medical Terms in the Jakarta Post'S Articles, JEET., 2(2), 93-102 (2018) 
12. Etymology Online Dictionary, (October, 2017), Who did this?, Retrieved from https://www.etymonline.com/columns/post/bio?utm_source=etymonline_footer\&utm medium=link_exchange

13. Vocabulary.com, Retrieved from https://www.vocabulary.com/ 